\title{
STEREOTYPE IMPACT ON CONTEMPORARY SOCIETY
}

\author{
F. N. Mocănaşu
}

\section{Florentina Nina Mocănaşu}

Faculty of Law, Journalism, Psychology and Educational Sciences, Hyperion University, 90-92 Popa-Nan St., Bucharest, Romania

*Correspondence: Florentina Nina Mocănaşu, Hyperion University, Bucharest, Romania Email: motornina@yahoo.com

\begin{abstract}
On analyzing the society we live in, we can say that transition from industrial to modern and postmodern society up to now has led to a change of the roles well established by our society, namely women perform men's tasks and they get jobs which seem specific to them, and men start to develop furthermore this side of relationing which is basically specific to women. The household issues are solved by both life partners and within organizational environment women have begun to occupy important executive positions. However, there are specific stereotypes including at the level of these changes.

Stereotype analysis draws our attention to interpretations which might devalue individuals or create a negative context without allowing any possibility to exploit certain potentials of individuals. However it is necessary to recognize the complementarity between the two genders. Stereotypes are more and more underlined in the Romanian society as they keep on perpetuating. The emergence of these stereotypes owes basically to changes occurred within society.

This study seeks to show the way these transformations aim the individuals' lifestyle and how these stereotypes coordinate our entire existence. There are opinions and discriminations within a society in relation to personalities of individuals which are part of a certain social category and we learn the most of them from the ones around us and depending on them we guide ourselves when meeting people. Stereotypes are harmful in their meaning and they hurt us by prejudice and discrimination.
\end{abstract}

Keywords: stereotypes, discrimination, change of roles, complexity of genders, transformation

Motto:

We do not see before defining, but define before seeing.

\section{Introduction}

\section{Identification of stereotype notion}

Cambridge dictionary explains the notion of stereotype as a "fixed idea people have about something or somebody, in particular about something wrong". "According to the same dictionary, prejudices are "an opinion or an unfair and unreasonable feeling formed without enough thought or knowledge". ${ }^{2}$ In other words, stereotypes are preconceptions, clichés which individuals use frequently while prejudices are irrational feelings of fear and dislike. These can be understood as protection filters against the multitude of information which allows us to judge people without interacting personally with them or knowing them only superficially: they limit our view to reality.

\footnotetext{
${ }^{1}$ Boia, Lucian, Istorie şi mit în conştiinţa românească, $2^{\text {nd }}$ Edition, "Humanitas" Publishing House, Bucharest, 2000 , pp. 112.

${ }^{2}$ Idem, pp. 123.
} 
These situations arise because we communicate differently and each of us has his own style to communicate as we use it differently depending on our social, professional and cultural identity, turning into resources which make communication possible. The more familiar speakers are with the context of a situation, the more they can manipulate the respective situation giving it another connotation. Sociologists and specialists in communication sciences often emphasize that both individual and collective actions are visible due to rituals, social rules and practices.

One of the most striking things in relation to stereotypes and prejudices is that they are regularly created by persons with strong personalities and applied to individuals with weak personalities which cannot control the way others perceive them and they cannot change these perceptions. Individuals who suffer from stereotypes are not those whose feelings of fear are exploited, but those persons who are shown in a negative light. Stereotypes and prejudices are so deeply rooted in the European culture that many times they are not perceived as such, but as an ordinary, usual fact. Those who suffer from them must embark on a long exhausting way to convince others that they are unreasonably discriminated. namely ${ }^{3}$ :

In relation to stereotype formation, there are three ways to explain this process,

$>$ Stereotypes arise because human mind works as such, cognitive processes lead to stereotyping;

$>$ The main reason for classification and discrimination is the fact that our personality makes us to use them or we use stereotypes in order to respond to certain psychological needs;

$>$ There are social factors that constrain us to have this restrictive view on society.

Stereotypes and social rules between adults and children children:

Examples of stereotypes which are frequently used in relationships between adults and

- $\quad$ "How are we supposed to buy this pink teddy bear? It's for little girls, not for boys. Let's look for another toy suitable for you".

"I told you not to play in the mud. You are being dirty all day as if you were a boy not a girl. Look at the other little girls, they are all clean and they wear dresses, only you are full of mud" they are reactions which many parents have when their children show preferences which are "not appropriate" to behaviors specific to boys, respectively to girls.

There are disproportionate requirements for children of a specific gender:

- "Boys don't cry",

- "Girls must be tidy, learn to cook and to clean",

- "Boys must be strong and girls delicate",

- "Boys are better at mathematics, exact sciences than girls",

- "Girls must be good at handiness activities (sewing, for instance)".

Such stereotypes underlie discrimination in various situations: girls who are not encouraged to develop a career in fields dominated by men or boys who are socially rejected because they have a more "gentle" behavior than they "should".

The environment where children learn these frequent prejudices are as follows:

- from TV;

- from video games;

- on internet;

- from school;

- in the family;

- from ads;

\footnotetext{
${ }^{3}$ Antonesei, Liviu, Fundamentele culturale ale educaţiei, Polirom Publishing House, Iaşi, 1996, pp. 11-12.
} 
- from books.

Children are not born with stereotypes and they do not learn them either as if a poem, they born from interaction with people. Prejudice represents the affective dimension associated to stereotypes and stereotypes are preconceptions. ${ }^{4}$ They are a fixed opinion someone has about something or someone else without knowing many things about it. These fixed ideas are unfair and unjustifiable and made up of erroneous knowledge and a generalization which arises in relation to them. Prejudice leads to hate, hate leads to radicalism expressed in words and the radicalism of words leads to radicalism of facts. If these arguments are complemented by the fact that children watch plenty of stereotypical situations at TV and mass-media and they watch cartoons and games which built inside their personality violent reactions then those children will become some stereotypical adults.

Voltaire claims that "Prejudice is an opinion without judgment"s, it is formed without a real knowledge about a person or a group of people. Prejudices involve stereotypes, which represents generalizations of some individual aspects to a whole group.

Stereotypes and prejudices show in time that the child's skills and interests haven't been valued. A stereotype like "Girls do not hockey, only boys", does not allow girls which might be champions at this sport to use and value all her innate abilities thereof. The same happens with ballet in case of boys who are not allowed to practice it because it turns them into "girls". Sport is meant to develop our body, to create a discipline for individual, to show him how a positive competition is created and not to create him stereotypes or prejudices whatsoever.

\section{Social environment of stereotypes}

Most stereotypes are visible in social environment or better said in the environment we live in. Most of the time they are related to the group we belong to, then with community we live in and last but not least what we call the "culture" we are born in. Stereotypes are difficult to change and most of the time they are perpetuated and transmitted from generation to generation, recognized to be values by many individuals.

Mass-media, leaders of opinion, opinion polls, conversation networks, sometimes even ad speech, commercials generate first a tacit pressure on individuals and subsequently they lead to stereotypes.

These stereotypes are fueled by social memory, by traditions and rituals, common symbols. They are induced by mental structures which some member of a community might have and they are formed by a process of indoctrination, fact that worked very well during communism regime we passed through. This indoctrination is intended to replace certain social, family, cultural values from the individuals' collective mind with others values deemed to be indispensable at that time. ${ }^{6}$ They were present everywhere in people's lives,

\footnotetext{
4 Iliescu Laura Jiga, Despre Europa în cultura populară românească a secolului al XVIII-lea, in Interculturalitatea - studii, cercetări, experienţe, "Centrul Educaţia 2000+" Publishing House, Bucharest, 2007, pp. 114.

${ }_{5}^{5}$ Durandin, Catherine, Une mort roumaine, Paris, Éditions Guy Épaud, 1988, pp. 87. See the historical esseys and fiction about Romania by the same author: Ceausescu, vérités et mensonges d'un roi communiste, Paris, Éditions Albin Michel, 1990; Histoire de la nation roumaine, Paris, Éditions Complexe, 1994; Histoire des Roumains, Paris, Éditions Fayard, 1995 (Romanians' history, Iaşi, “Institutul European” Publishing House, 1998).

${ }^{6}$ Foucault, Michel, Altfel de spaţii, in Theatrum philosophicum. Studii, eseuri, interviuri. 1963- 1984, "Casa Cărţii de Ştiinţă” Publishing House, Cluj-Napoca, 2001, pp. 251-60;
} 
starting with children and ending with old people (literature, education, music etc.). The formulas used in the communist regime were: formation of a new individual, education of a multilateral developed personality, scientific organization of work. In fact, behind these short phrases there were totally different intentions. In order to control people there was only one way that of unification namely of stereotype introduction.

Discrimination is the action induced by prejudices and it means unequal treatment applied to individuals or groups in relation to ethnicity, religion, social category, gender, aspect and others. Stereotypical thinking is a long-term process which starts always from childhood, in family and continues in school, group of friends. Much easier, we can say that stereotype is: we are plus and you are minus, as we have always tended to consider people different from us not only different but inferior. This mean san important source of world conflict: (Holocaust, genocides and violent racist conflicts)

Stereotype and prejudice change can be achieved by ${ }^{7}$

- underlying some representatives of the group where we identify the existence of some stereotypes which refutes the stereotype.

- providing a significant amount of information in relation to that group - concerning all the values and norms specific to it and their members; - motivating individuals to understand properly the group they want to communicate with; - involving in activities with regard to achieve common goals; - identification of our own stereotypes and prejudices is essential on achieving a real communication on long term among various cultural groups. It is also the first step to the other one and development of new perspectives on cultural groups we interact with.

Each of us puts labels or has certain stereotypes at a given time. They can prevent us from seeing reality as it is.

Stereotype is perhaps the best known notion of social psychology next to discrimination and prejudice. ${ }^{8}$ These occur in intergroup relationships and not between singular individuals, consisting of generalization of some attributes met in few members of a group over all the persons belonging to that group. Each of us forms part of different groups and social categories, based on some characteristics which distinguish them from others. It may be the age, social category, race, gender, field of activity, observing a tendency to favor the group we belong to in the detriment of external groups. It is about a society division into us and them which makes us to "admire and praise ourselves" but to depreciate and denigrate them, to be on our people's side and not theirs".

In a hierarchically organized society, individuals have a certain behavior to their superiors and another one to those situated on a lower position and that's why there are stereotypes and lies as they can be directed in both ways. Individuals are always surrounded by social constraints, especially by inherited obligations which can't be explained if analyzing individuals' behavior only. Social facts have social causes different from psychological ones and these causes are different from their functions. Compliance with social rules by individuals must not lead them to certain discriminations or stereotypes as they constrain the individuals and they also provide them opportunities.

\footnotetext{
${ }^{7}$ Nemoianu, Virgil, Tradiţie şi libertate, "Curtea Veche” Publishing House, Bucharest, 2001, pp. 144;

${ }^{8}$ Todorova, M., Balcanii şi balcanismul, Humanitas Publishing House, Bucharest, 2000, pp. 47-54;
} 
Many times people are not sure of their capacities and opinions because the observations on their personalities are not objective and then they self-assess by comparison with other similar individuals. On each assessment, individuals tend to use stereotypes like "Mr. Such is...in comparison with me... but I have more...than him." When we answer the question "whom do we compare with?" the answer is that we usually compare ourselves with those similar to us, avoiding to make comparisons with others much more efficient than us for not to feel inferior.

There are plenty of stereotype beliefs perpetuated by adults in our contemporary society ${ }^{9}$ :

- $\quad$ All gypsies are sly, lazy and thieves;

- $\quad$ All Hungarians are chauvinistic, conceited and irredentist;

- All Russians are alcoholic, cruel and sentimentalist;

- $\quad$ All English are phlegmatic, snobs and pragmatic;

- $\quad$ All Japanese are hardworking;

- $\quad$ Athletes are not quite intelligent;

- $\quad$ All librarians are silent;

- All accountant are boring;

- $\quad$ All teachers are pedantic;

- $\quad$ All students are absent-minded and unserious.

We can realize that these stereotypes are not realistic, although they exist and make individuals behave many times unduly in relation to the categories they once disfavored. People usually behave inadequately with their fellows when their self-esteem is threatened by a failure in performing an important task these are much more motivates to negatively stereotype the others for a self-image improvement. Stereotype activation is facilitated and stimulated by the presence of some members of stereotyped groups ${ }^{10}$.

\section{Effects of stereotypes in society}

No individual can escape from labeling and we all are the target of the others' stereotypes and prejudices; we are stereotyped and treated differently depending on how we look, how we talk and where we come from. If labeling comes in a moment of life when selfesteem is low, then the danger is bigger as the respective person adopts a more and more indecisive behavior, loses his motivation which may lead to dishonorable acts for society on long term. If social influence represents the way people are affected by real or imaginary pressure the others exercise over them, then this may determine individuals to behave the way they were labeled due to stereotypes, even if they know that stereotype is not real and it is obvious to happen this, because we form our self-identity and the games we play in society and they way we are perceived by others. Stereotypes disarm people, kill their potential and aspirations and make discriminated persons feel ashamed of what they are even without having done something reprehensible. Stereotypes and their evil effect and superiority reduce the success opportunity of some initiatives intended to cause a change in "bad reputation" communities".

Stereotypes do as much harm as those who use and perpetuate them. Besides they poison their soul and spirit, they keep them away from the truth and a genuine knowledge of reality...namely they affect their development too. When someone uses stereotypes in his speeches, replaces the complexity of situations and various shades, with a simple, rigid thinking closed to new and change namely to life itself which changes incessantly. In other words, stereotypes keep prisoners the minds of those who express, defend and perpetuate them.

\footnotetext{
${ }^{9}$ Yuval-Davis, Nira, Gen şi naţiune, “Univers" Publishing House, Bucharest, 2003, pp. 9;

${ }^{10}$ Idem, pp. 38.
} 


\section{Bibliography}

Iliescu Laura Jiga, Despre Europa în cultura populară românească a secolului al XVIII-lea, in Interculturalitatea - studii, cercetări, experienţe, "Centrul Educaţia 2000+" Publishing House, Bucharest, 2007;

Yuval-Davis, Nira, Gen şi naţiune, "Univers" Publishing House, Bucharest, 2003;

Baudrillard, Jean, Guillaume, Marc, Figuri ale alterităţii, "Paralela 45" Publishing House, Piteşti, 2002;

Duţu, Alexandru, Ideea de Europa şi evoluţia conştiinţei europene, ALL Publishing House, Bucharest, 2002;

Foucault, Michel, Power, "Essential Works of Foucault", 1954 - 1984", Vol. 3, London, New York, Penguin Books, 2002;

Schöpflin, George, Nations, Identity, Power. The New Politics of Europe, London, Hurst and Company, 2002;

Foucault, Michel, Altfel de spaţii, in Theatrum philosophicum. Studii, eseuri, interviuri. 1963- 1984, "Casa Cărţii de Ştiinţă" Publishing House, Cluj-Napoca, 2001;

2001 ;

Nemoianu, Virgil, Tradiţie şi libertate, "Curtea Veche" Publishing House, Bucharest, 2000;

Alexandrescu, Sorin, Identitate în ruptură, "Univers" Publishing House, Bucharest,

Boia, Lucian, Istorie şi mit în conştiinţa românească, 2nd Edition, "Humanitas" Publishing House, Bucharest, 2000;

Lascu, Gh., Imaginea Franţei la românii din Transilvania până în anul 1918, "Casa Cărţii de Ştiinţă’” Publishing House, Cluj Napoca, 2000;

Todorova, M., Balcanii şi balcanismul, Humanitas Publishing House, Bucharest, 2000 ;

Leisering, Lutz, Leibfried, Stephan, Time and Poverty in the Western Welfare States United Germany in Perspective, Cambridge University Press, Cambridge, 1999;

Swartz, Richard, Room Service. Povestiri din Europa de Est, "Univers" Publishing House, Bucharest, 1999;

Antohi, Sorin, Exerciţiul distanţei. Discursuri, societăţi, metodei, Nemira Publishing House, Bucharest, 1998;

Andreß, Hans-Jürgen, Katia Schulte, "Poverty risk and the life cycle: The individualization thesis reconsidered", in Andreß, Hans-Jürgen (coord), Empirical Poverty Research in a Comparative Perspective, Ashgate, Aldershot, Brookfield USA, Singapore, Sydeny, 1998;

Buhr, Petra, Weber, Andreas, "Long-term Recipiency of Social Assistance in Germany: The Eighties versus the Nineties", in Andreß, Hans-Jürgen (coord), EmpiricalPoverty Research in a Comparative Perspective, Ashgate, Aldershot, Brookfield USA, Singapore, Sydney, 1998;

Friedrichs, Jürgen, "Do Poor Neighborhoods Make Their Resident Poorer?", in Andreß, Hans-Jürgen (coord), Empirical Poverty Research in a Comparative Perspective, Ashgate, Aldershot, Brookfield USA, Singapore, Sydeny, 1998;

Jalan, Jyosna, Ravallion, Martin, "Determinants of Transient and Cronic Poverty", Policy Research Working Paper1936, World Bank, 1998;

Bouhris, Richard, John Turner, Andre Gaugnon (1997), "Interdependence, Social Identity and Discrimination", in Oakes, Penelope, Naomi Ellemers, Alexander Haslam (coord.), The Social Psycholgy of Stereotiping and Group Life, Blackwell Publishers, Oxford, Cambridge, Massachusetts, 1997;

Mitu, Sorin, Geneza identităţii naţionale la românii ardeleni, Bucharest, 1997;

Ellemers, Naomi, Ad van Knippenberg (1997), "Stereotyping in Social Context", in Oakes, Penelope, Naomi Ellemers, Alexander Haslam (coord.), The Social Psycholgy of Stereotiping and Group Life, Blackwell Publishers, Oxford, Cambridge, Massachusetts, 1997; 
Wischembart, Rüdiger, Frica lui Canetti, 1997;

Yzerbyt, Vicent, Steve Rocher, George Schadron, "Stereotypes Explanations: A Subjective Essentialistic View of Group Perception" in Oakes, Penelope, Naomi Ellemers,Alexander Haslam (coord.), The Social Psycholgy of Stereotiping and Group Life, Blackwell Publishers, Oxford, Cambridge, Massachusetts, 1997;

Antonesei Liviu, Fundamentele culturale ale educaţiei, Polirom Publishing House, Iaşi, 1996;

Stangor, Charles, "Stereotype", in Manstead, Anthony, Miles Hewstone - The Blackwell Encyclopedia of Social Psychology, Blackwell, Oxford, 1995;

Said, Edward, Culture and Imperialism, London, Vintage, 1994;

Murphy, Dervla, Transylvania and Beyond, London, Arrow Books, 1993;

Durandin, Catherine, Une mort roumaine, Paris, Éditions Guy Épaud, 1988;

Mitchel, Deborah, Kenneth Cooke, "Cost of Childrearing", in Walker, Robert, Gillian Parker (coord.), Money Maters - Income, Wealth and Financial Welfare, SagePublications,London, Newbury Park, Bevely Hills, New Delhi, 1988;

O'Hinggis, Martin, Jonathan Bradshow, Robert Walker, "Income Distribution Over the Life Cycle", in Walker, Robert, Gillian Parker (coord.), Money Maters - Income, Wealth and Financial Welfare, Sage Publications, London, Newbury Park, Beverly Hills, New Delhi, 1988;

Bane, Mary Jo, Ellwood, David, "Slipping Into and Out of Poverty", in The Journal of Human Resources, vol. 21, Nr.1, 1986;

Bahtin, M., Probleme de literatură şi estetică, "Univers" Publishing House, Bucharest, 1982, (chapter "Discursul poetic şi discursul romanesc");

Tajfel, Henry, "Social Stereotypes and Social Groups", in J.C. Turner, H. Giles, Intrgroup Behaviour, Blackwell, Oxford, University Press of Chicago, Chicago, 1981. 